KAIROS ELT JOURNAL, Vol. 2, No. 1, April 2018

Copyright@2018, ISSN: 2580-4278

\title{
IMPROVING STUDENTS' SPEAKING SKILL THROUGH STORY TELLING TECHNIQUE TO THE ELEVENTH GRADE STUDENTS OF SMA SWASTA KATOLIK BUDI MURNI 2 MEDAN
}

\author{
Veronika Dasniati Tambunan, Viator Lumban Raja, Anna Stasya Prima Sari \\ Catholic University of Saint Thomas
}

\begin{abstract}
This research was conducted in order to improve students' speaking skill through story telling technique to the eleventh grade students of SMA Swasta Katolik Budi Murni 2 Medan. In conducting this research, the writer used Classroom Action Research (CAR). This reaearch showed that teaching speaking skill through story telling technique to the eleventh grade students of SMA Swasta Katolik Budi Murni 2 Medan could improve their speaking skill. The result of the this research showed that the students' responses after being taught by using story telling technique are very good. The result of the test showed the students' mean score in pretest is 57,37 with $20 \%$ of the students got score $\geq 70$, in formative test mean score is 70,85 with $60 \%$ of $t$ he students got score $\geq 70$ and in posttest mean score is 80,05 with $88,57 \%$ of the students got score $\geq 70$. The research findings showed tha the application of story telling technique could improve the students speaking skill. It is advisable that English teachers apply story telling technique as a technique in order to improve their students' speaking skill.
\end{abstract}

Keywords: Story Telling Technique, Speaking Skill

\section{INTRODUCTION}

Language as a means of communication is no longer debateable. Language has an important role in human life because without language there is no communication and it will be difficult for people to understand what other people mean. Without communication, people will be left behind. Language is an instrument to share information and discuss something people need. Communication in foreign language is a bridge to get information, knowledge, and culture.

One of the languages which is widely spoken all over the world is English. Indonesia as a developing country has realized that English as an international language is needed to be mastered by Indonesian people. English is one of foreign languages which is taught from elementary level to university level. In English learning there are four skills. They are listening, speaking, reading and writing. The four aspects are important but speaking is the most important to be mastered since it measures how good learner's in understanding the language. Speaking is the first way to interact with others in the social community. Furthermore, the success in learning a language at first can be seen from the ability of the learner's speaking. Richards and Rodgers (1986: 110) state, "Speech was regarded as the base of language, because language, in principle is sound". This mean that the product of learning a language is speaking. Therefore, the final goal of learning a language is able to communicate with that language.

Speaking is an activity used by someone to communicate with other. It takes place everywhere and has become part of our daily activities. When someone speaks, he or she interacts and uses the language to express his ideas, feeling, and thought. He also shares information to other through communication. Speaking is one of the productive skills and two way process between speaker and listener.

Based on the experience of the writer when she did the internship program at SMA Swasta Katolik Budi Murni 2 Medan in the Academic Year 2016/2017, it was found out that the students always thought that speaking was hard and not enjoyable due to the lack of 
vocabulary and grammatical knowledge. Thus, when the teacher asked them to practise speaking, they were not brave enough to speak up, especially in front of the class. Sometimes, they also felt anxious and less confident about their speaking, pronunciation, or grammar.

The problems above should be immediately solved. Teachers have to consider a technique that can help their students solve their problem in order to have good speaking skill. There are many techniques that can be applied to improve students' speaking skill. They are oral prasentation, role play, debate, story telling etc. The writer chose story telling technique to solve the students' problems in speaking English.

Story telling is one of interactive activities of using words and actions to reveal the elements and images of a story while encouraging the listener's imagination. Story telling involves a two-way interaction between a storyteller and one or more listeners. It is to retell the story having read or heard by using the story tellers' own words based on their understanding about the story. According to Harmer (2007: 89) story telling is one of the ways in teaching speaking. Students can briefly summarize a tale or story they heard from somebody beforehand, or they may create their own stories to tell their classmates. Thus, the students can share their ideas in story telling. By implementing story telling, there are many benefits for teacher and students, such as improving students' vocabulary, self-confidence, ability to pick up appropriate words, etc.

The writer is interested in applying story telling technique in order to improve students' speaking skill because some researchers' findings have shown good results of teaching speaking skill through story telling technique. The first research was carried out by Munaroh (2012) entitled "Using Story Telling Technique to Improve Speaking Skills of the Students of MTS Al-Ghozali Panjerejo". It statically had been proven by the increase of the students' mean score in post-test which is higher than the mean score in pre-test. The mean score increased from 20.7 in pretest to 31.03 in posttest I and 86.21 in posttest II. She concluded that there was an improvement in speaking skills of the students of MTs Al-Ghozali Panjerejo. The result shows that most of the students are quite interested in implementation of story telling technique. Those mean that story telling technique is effective to improve speaking skills of the students of MTs Al-Ghozali Panjerejo. The second one was carried out by Purwatiningsih (2015) entitled "Improving Speaking Ability through Story Telling Technique by Using Picture Series to the Tenth Grade Students of MAN 2 Madiun in Academic Year 2014/2015. It statically had been proven by the increase of the students' mean score in post-test which is higher than the mean score in pre-test. The mean score increased from 50.15 in pretest to 68.5 in posttest I and 77.6 in posttest II. She concluded that there was insignificant improvement on the mean score when it was compared with the mean score of pretest. The third one was carried out by Halimah (2016) entitled "Improving the Students' Vocabulary Mastery by Using Story Telling". It statically had been proven by the increase of the students' mean score in post-test which is higher than the mean score in pre-test. The mean score increased from 5.4 in pretest to 6.9 in posttest I and 7.2 in posttest II. The mean score from pretest to posttest improves insignificantly because the increase does not show a big difference. However, the students are able to pick up the word meaning based on the context.

If this study is conducted, it will give some positive impacts. This study will be useful for language teachers, so they will be able to know how far the students' speaking skill improves. Based on the background of the study, the writer decides to conduct a research entitled "Improving Students' Speaking Skill through Story Telling Technique to the Eleventh Grade Students of SMA Swasta Katolik Budi Murni 2 Medan”.

\section{REVIEW OF LITERATURE 2.1 Speaking}

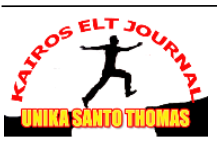


Speaking is the second skill of language after listening that needs a kind of practice such as how to pronounce the word to make tone, pitch, intonation, etc. In other words, speaking is an ability to say or state something so that people can get the idea or message that we deliver to. This activity at least involves two persons in which they share any kind of information they have. It seems there must be a pause between the speaker and listener in exchanging the information. This activity will help them to get any kind of information they need.

Lado (1961: 240) states that speaking as the ability to express oneself in life situation, or the ability to report acts or situations in precise words, or the ability to converse, or to express a sequence of idea fluently. This ideas means that speaking emphasizes more on the ability of an individual to convey something whether it is in the form of expression, report with the language he has.Speaking must be practiced as often as possible in order to improve communicative skills. A conversation between two or more people is a blend of listening and speaking where the comprehension of what has been said is necessary for what each participant says next.

According to Fisher \& Frey (2007: 16) speaking is the uniquely human act or process of sharing and exchanging information, ideas, and emotions using oral language. The goal of speaking is to achieve an interactive communication between the speaker and the listener. Teaching speaking is the activity where the teachers lead their students to improve their ability in expressing emotions, ideas or feelings orally.

From the explanation above it can be concluded that people should have the ability to convey the information, ideas, feeling to others in oral language. Therefore, the teaching of speaking should get more attention in the classroom.

\subsection{Speaking Skill}

Speaking skill is the productive skill in the oral mode. Like other skills, speaking is more complicated and involves more than just pronouncing words. Harris (1969: 81-82) states that there are five components of speaking skill that can be defined as follows: pronunciation, grammar, vocabulary, fluency and comprehension. To be a good speaker the English learners have to master all of the components. However, besides those linguistic components above there are many factors that influence speaking ability. According to Turk (2003: 5) if we want to improve speaking skills first we must be aware of ourselves, our motivations, behavior patterns, and probable mistakes. From that statement it can be concluded that our own motivation and also our environment are the influential factors in improving speaking skill. If the learners have a high motivation to improve their speaking skill, they will study hard and find many sources and model about speaking skill. The environment is the next important factor that influences learners' speaking skill, because if people around the learners are able to speak well it will be easily for the learners to copy their way how to speak. Therefore, environment holds an important role to help learners develop theirspeaking skill. If the language is not available in the environment, it will take a long time to develop the speaking skill because the language is restrictly used in the classroom.

Speaking skill becomes the important aspect of language when studying the language especially English without practicing to speak is useless. Speaking skill is important thing to be mastered when people learn English because speaking is a process of constructing meaning; it covers almost all of language components. Through speaking someone can express their minds, ideas, and thought freely and spontaneously. In addition, the purpose of teaching speaking is to guide both the teachers and students to use the target language as frequently as possible, especially during the learning process.

In the global era speaking ability in English is useful in many situations and places. In the world business, English become the language and in applying for a job, English is 
absolutely required. When one continues for further study abroad, English is absolutely necessary. In addition, most of scientific books are written in English. All these oblige us to master English.

\subsection{Teaching Speaking}

Teaching speaking starts with pronouncing words clearly to be imitated by the students. Then, the words are developed into sentences to be drilled. The teacher should be aware of the sounds being pronounced. Then,it is continued to guide students to a point where they can begin to judge whether their sound productions are correct or not. At this point, teacher is no longer primarily to correct, but he or she is supposed to encourage students to practice the target language. Meanwhile, the teacher should be able to encourage students to pronounce some sounds which are absent in their mother tongue, repeating, and imitating him/her. Finally, the students are required to practice and drill the language. Additionally, Ur (1996: 120) says that the successful speaking activity has the characteristics as follows:

1. The language learners talk so much.

2. All the participants of speaking activity get the opportunity to.

3. The language learners are highly motivated and have interest in the speaking.

4. The language produced is at the acceptable level.

To support the teaching learning process of speaking skill, the teachers must know about the characteristics of students and also the characteristics of successful speaking activity. If the teacher knows about the characteristics of each student,he can easily make the approach to the students.

In teaching speaking there are some techniques that is used. According to Harmer (2002: 271) many of classroom speaking activities are currently used:

1. Acting from script

This activity encourages students to act out scenes from plays or their course books, sometimes filming the result. Students will often act out dialogues they have written themselves. This frequently involves them in coming up to the front of the class, and speaking up their lines.

2. Communication games

Speaking activities based on games are often a useful way of giving students valuable practice, where younger learners are involved. Games based activities can involve practice of oral strategies such as describing, predicting, simplifying, and asking for feedback.

3. Discussion

One of the reasons that discussion fails is that students are reluctant to give an opinion in front of the whole class, particularly if they cannot think of anything to say and are not confident of the language they might use to say it. Many students feel extremely exposed in discussion situations. They might not have enough background about the topic being discussed so that they do not know what they say about it. This makes the discussion not work well.

4. Simulation and role-play

Many students derive great benefit from simulation and role-play. Students simulate a real life encountered as if they are doing so in the real world. A simulation and role-play can be used to encourage general oral fluency to train students for specific situation.

5. Debate

Debate is an activity in which opposite points of view are presented and argued. Debate can present opportunities for students to engage in using extended series of language for a purpose to convincingly defend one side of an issue.

All speaking activities above encourage students to practice speaking in classroom. Teacher should choose appropriate activities above based on the level of the students. Every

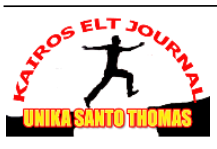


teaching and learning process can be enjoyable if teacher gives the appropriate activity based on students' levels. The writer chooses one of the techniques in teaching speaking that is acting from script. Because when the teacher ask the students to speak in front of the class, with the script the students will easy to memorize and understand what they want to say appropriate with the script. Besides, the process of transferring knowledge can be easy done.

\subsection{The Problems in Teaching Speaking Skill}

Students sometimes have some problems when they actually want to talk in front of public, or in this case is talk in front of the classroom. According to Ur (1996: 97-98) the problems in speaking activities are as follows :

1. Inhibition. Students are often inhibited about trying things in foreign language classroom, afraid to make mistakes or to be criticized, and shy to utter words.

2. Nothing to say. Students sometimes find fault that they do not have something to say. In other words, they cannot express themselves.

3. Low or uneven participation. Only one participant talks because of some learners dominate, while other speaks a little or not at all.

4. Mother tongue use. In the class, all students share the same mother tongue, so they feel unnatural to speak in the foreign language. They are also less exposed and less disciplined or motivated one.

Based on the problems above, it is suggested to the teacher to choose the suitable way or method in line with the problems that they found in their teaching. Teacher can also engage students in conversation or as an example of the lesson provided by the teacher to the students.

\subsection{Story Telling}

Story telling has been used as a means of communication since earliest times. Stories create magic and a sense of wonder at the world. Stories teach us about life, about ourselves, and about others. Story telling is a unique way for students to develop an understanding, respect, and appreciation for other culture. According to Taylor (2000: 6) story telling is a tale to one or more listener through voice and gesture. In oral telling, we usually repeat things to make them clearer, especially if the students are having difficulty to follow it.

Moreover, Safdarian (2013: 208) states that story telling is the way of the students to retell stories in a different word construction after they are told by the teacher. Thus, it can be said that storytelling is a teaching method in which the students are asked to retell the content of the stories in different word constructions by involving a certain interaction between the storyteller and the listener through voice and gesture. As human being, people usually tell their story to others. They tell others about their feeling, opinion, ideas, or even anything happened in their lives. It is very simple to tell story to others, as simple as expressing what is on mind. Story telling makes the vocabulary easy to remember, and also makes the children easy to learn English and improve their speaking skill (Silaban \& Limbong, 2017).

Coconi (in Inayah, 2015: 31-32) states, there are some types and purposes of story telling:

1. Cultural Story telling

Cultural story telling is defined by the transmitting and conveying of certain values, morals and beliefs. These stories are passed down from generation to generation in engaging memorable form. The stories that are given to children is an attempt to teach them the meaning of religion which might be understood as cultural stories.

2. Family Story telling

Family story telling is thought of as the spoken history of a family, maintaining and preserving a long line of various events and experiences, while keeping traditions and expectations alike. Story telling that concerns a family heritage allows for a family identity to emerge, often bringing with it the finest traits of an ancestral history as a reminder to live

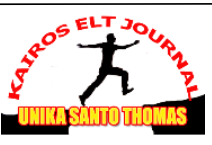


up to something. This type of story can provide those who hear it with the motivation to live up to past family achievements.

3. Personal Story telling

Through living, everyone is in the constant and ongoing process of composing a personal story. The stories are formed personally and concern individual lives. They are composed to remember, change and find meaning to life. Through personal story telling, the teller is able to share his experiences with others and possibly motivate and inspire. Personal story telling might also take the form of a biography or a biographical novel.

From the explanations above it can be concluded that telling stories gives us a sense of culture, history of family, personal identity and a doubtful stories. It makes sense out of our lives. Sharing stories allows us to understand the human experience and find ways to relate to and connect with one another.

\subsection{The Objective of Story Telling}

According to Ellis \& Brewster (1991: 1-2) there are some objectives in doing storytelling technique in speaking class. The first objective is to motivate students to develop positive attitudes towards the foreign language and language learning. In every story, there will be a moral message that can be taken, whether it is negative or positive. If it is negative, teacher must tell the students not to copy, but if it is positive, teacher must tell the students to do so.

The second objective is to exercise students' imagination. Students can become personally involved in a story as they identified with the characters and try to interpret the narrative and illustration. They can also think fantasy and imagination to their real world. This imaginative experience helps to develop their own creative powers to make sense of their daily life.

The third objective is to increase students' ability to share social experience. Storytelling is not only enjoyable, but can help build up students' confidence and encourage social and emotional development. It provokes a shared response of laughter, sadness, excitement, and anticipation.

The fourth objective is to allow teacher to introduce or revise new vocabulary and sentence structures. It can be done by exposing the students to language in varied, memorable and familiar contexts. It will enrich their thinking and gradually enter their own speech.

The fifth objective is to improve students' other skills in some aspects, such as listening, grammar, vocabulary, and concentrate. In using story telling technique for speaking class, the teacher must be fair in choosing the storyteller. The story teller must be chosen in rotation, so every student will get their turn to be storyteller. There will be also listener who can improve listening, grammar, vocabulary, and concentrate through the storyteller.

From those five objectives of storytelling, it can be concluded that storytelling gives many benefits besides improving speaking skills. Other skills that can be improved through storytelling are listening, grammar, vocabulary, and concentration. Storytelling is also a convenient activity to improve speaking skills because students can express their experience, opinion, ideas, and hopes.

\subsection{The Implementation of Story Telling in Speaking Class}

In implementing story telling, it isimportant to look at the procedures. Samantaray (2014: 42) describes the procedures of implementing story telling in the classroom as follows:

1. the teacher hangs different written stories with colorful papers on the white board,

2. the teacher asks the students to make groups of five,

3. the teacher asks every group take a paper and choose the topic,

4. the teacher asks them to develop a story in 15 minutes,

5. the teacher asks them to retell their story based on the group discussion, and 
6. the teacher gives award to the group considered as the best group.

It is important to lookat the procedures of implementing story telling in classroom. By practising this procedures the sudents will implement the story telling as well as possible. They will get the best result of this procedures. The teacher is supposed to prepare the stories with different message which is familiar to the students. The unfamiliar stories will be difficult to retell because the students have no background knowledge about them.

\section{RESEARCH METHOD}

This research is Classroom Action Research (henceforth, CAR). This study was focused on teaching and learning in the classroom to make an improvement on students' achievement in speaking. CAR is different from quantitative and qualitative research, but has characteristics of both. An action research utilizes and has intervention to collect and analyze data.

In this study the writer tried to explain some theories relating to definition of action research according to the experts. According to Mills (2000: 6) action research is any systemic inquiry conducted by teacher, researcher, principals, school counselors, or other stakeholders in the teaching and learning environment, to gather information about the ways that their particular schools operate, how they teach, and how well their students learn. This information is gathered with the goals of gaining insight, developing reflective practice, effecting positive changes in the social environment and improving students' outcomes and the lives of those involved. The action research needs teachers to explore how they teach and how well their students learn in order to decide what the future practice is done by them and enhance the quality of education for the teachers and their students.

While, according to Burns (2010: 2) action research is part of a broad movement that has been going on in education generally for some time. It is related to the ideas ofreflective practiceand the teacher as researcher. In action research, a teacher becomes an investigator or explorer of his or her personal teaching context, while at the same time being one of the participants in it. It means that one of the main aims of action research is to identify problematic situation or issue the participants are faced with. They can be teachers, students, managers, administrators, or even parents.

\section{DATA ANALYSIS}

\subsection{The Data Analysis}

There are two types of data which were anlyzed to find out of the result of improving students' speaking skill by using story telling technique, they are quantitative and qualitative data.

\subsubsection{Quantitative Data}

The quantitative data was taken from the test result of students, namely pre-test before treatment, formative test after cycle one, post-test after cycle two. The complete result of the students' score in every test can be seen from (Appendix 1) the table and the histogram of score interval and frequency.

Table 1. Pre-Test Score Interval

\begin{tabular}{|l|l|l|}
\hline Score Interval & Frequency & Percentage \\
\hline $44-49$ & 8 & 22.85 \\
\hline $50-55$ & 8 & 22.85 \\
\hline $56-61$ & 10 & 28.57 \\
\hline $62-67$ & 2 & 5.71 \\
\hline $68-73$ & 3 & 8.57 \\
\hline $74-79$ & 3 & 8.57 \\
\hline
\end{tabular}

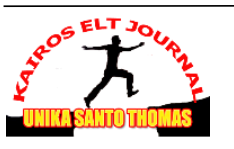


KAIROS ELT JOURNAL, Vol. 2, No. 1, April 2018

Copyright@2018, ISSN: 2580-4278

\begin{tabular}{|l|l|l|}
$80-85$ & 1 & 2.88 \\
\hline $86-91$ & 0 & 0 \\
\hline $92-100$ & 0 & 0 \\
\hline Total & $\mathbf{3 5}$ & $\mathbf{1 0 0}$ \\
\hline
\end{tabular}

Scoring interval is found by applying by this formula :

Scoring interval $(\mathrm{P})=\frac{R}{K}=\frac{X n-X 1}{1+3.3 \log n}$

Where :

a. The division of distance (R) $=\mathrm{Xn}$ (the highest)-X1(The lowest score) in which $\mathrm{X}_{\mathrm{n}}=80$ and $\mathrm{X}_{1}=44$

b. The sum of the whole data $(K)=1+3,3 \log n$

c. $n=$ the number of data, $\log 35=1.54$

Thus $\mathrm{P}=\frac{80-44}{1+3.3 \log 35}=\frac{36}{1+5,09}=\frac{36}{6,09}=5,91=6$

From the table of pre-test score interval and frequency, the writer presented the data of pre-test in chart.

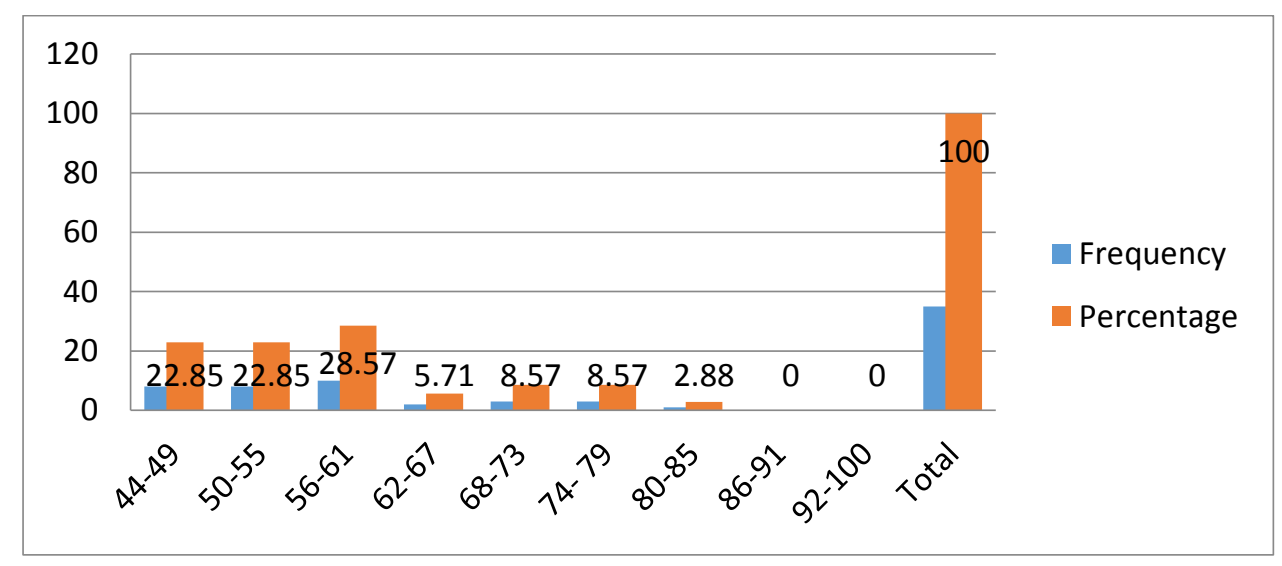

\section{Figura 1. The Histogram of Pre-test}

From the histogram of pre-test, the highest frequency for score interval 56-61 are 10 students $(28,57)$. There are 8 students $(22,85 \%)$ who occupy in score interval $44-49$ and $50-55$. The lowest of frequency for score interval 86-91 and 92-100 is 0. It means no student could achieve those scores. Then, the frequency for score interval $62-67$ are 2 students $(5,71 \%)$, the frequency for interval 68-73 are 3 students $(8,57)$, and 74-79 are 3 students $(8,57 \%)$. And the last frequency for score interval $80-85$ is 1 student $(2,88 \%)$.

Table 2. Formative Test Score Interval

\begin{tabular}{|l|l|l|}
\hline Score Interval & Frequency & Percentage \\
\hline $60-63$ & 4 & 11.43 \\
\hline $64-67$ & 3 & 8.60 \\
\hline $68-71$ & 8 & 22.85 \\
\hline $72-75$ & 10 & 28.57 \\
\hline $76-79$ & 8 & 22.85 \\
\hline $80-83$ & 1 & 2.85 \\
\hline $84-87$ & 1 & 2.85 \\
\hline $88-91$ & 0 & 0 \\
\hline
\end{tabular}


KAIROS ELT JOURNAL, Vol. 2, No. 1, April 2018

Copyright@2018, ISSN: 2580-4278

\begin{tabular}{|l|l|l|}
\hline $92-95$ & 0 & 0 \\
\hline $96-100$ & 0 & 0 \\
\hline Total & $\mathbf{3 5}$ & $\mathbf{1 0 0}$ \\
\hline
\end{tabular}

Scoring interval is found by applying by this formula :

Scoring interval $(\mathrm{P})=\frac{R}{K}=\frac{X n-X 1}{1+3.3 \log n}$

Where :

a. The division of distance $(R)=X_{n}$ (the highest)- $X_{1}$ (the lowest score) in which $X_{n}=84$ and $X_{1}=60$

b. The sum of the whole data $(K)=1+3,3 \log n$

c. $n=$ the number of data, $\log 35=1.54$

Thus $\mathrm{P}=\frac{84-60}{1+3.3 \log 35}=\frac{24}{1+5,09}=\frac{24}{6,09}=3,94=4$

From the table of formative test score interval and frequency, the writer presented the data of formative test in chart.

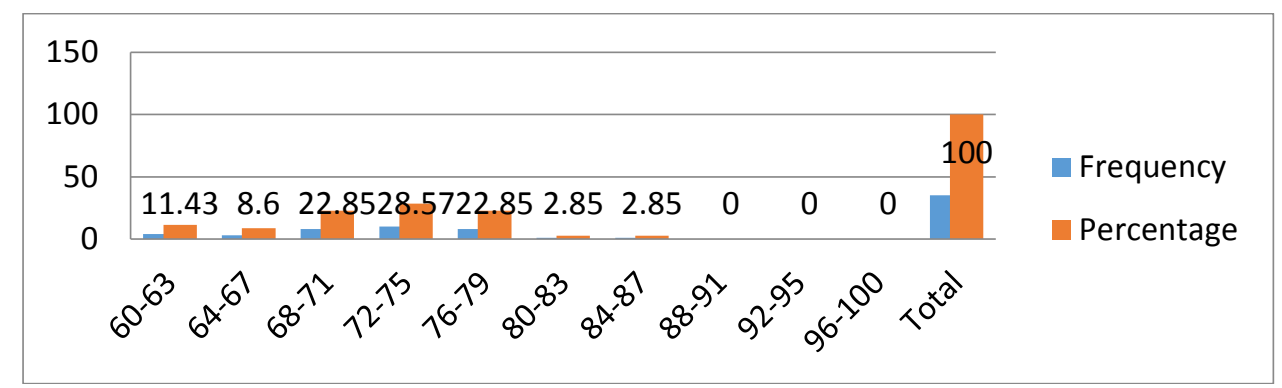

\section{Fugura 2. The Histogram of Formative test}

From the histogram of formative test, the highest score for interval 72-75 are 10 students $(28,57 \%)$. The lowest of frequency for score interval 88-91, 92-95 and 96- 100 is 0 . It means no student could achieve those scores. Then, frequency for score interval 84-87 is 1 student $(2,85 \%)$, the frequency for score interval $80-83$ is 1 student $(2,85 \%)$, the frequency for score interval 76-79 are 8 students $(22,85 \%)$, the frequency for score interval 68-71 are 8 students $(22,85 \%)$, the frequency for score interval $64-77$ are 3 students $(8,60 \%)$, and the last frequency for score interval $60-63$ are 4 students $(11,43 \%)$.

Table 3. Post- Test Score Interval

\begin{tabular}{|l|l|l|}
\hline Score Interval & Frequency & Percentage \\
\hline $68-71$ & 6 & 17.14 \\
\hline $72-75$ & 0 & 0 \\
\hline $76-79$ & 5 & 14.30 \\
\hline $80-83$ & 9 & 25.71 \\
\hline $84-87$ & 13 & 37.14 \\
\hline $88-91$ & 2 & 5.71 \\
\hline $92-95$ & 0 & 0 \\
\hline $96-100$ & 0 & 0 \\
\hline Total & $\mathbf{3 5}$ & $\mathbf{1 0 0}$ \\
\hline
\end{tabular}

Scoring interval is found by applying by this formula :

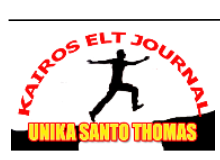


KAIROS ELT JOURNAL, Vol. 2, No. 1, April 2018

Copyright@ 02018 , ISSN: 2580-4278

Scoring interval $(\mathrm{P})=\frac{R}{K}=\frac{X n-X 1}{1+3.3 \log n}$

Where :

a. The division of distance $(R)=X_{n}$ (the highest) $X_{1}$ (the lowest score) in which $X_{n}=90$ and $X_{1}=68$

b. The sum of the whole data $(K)=1+3,3 \log n$

c. $n=$ the number of data, $\log 35=1.54$

Thus $\mathrm{P}=\frac{90-68}{1+3.3 \log 35}=\frac{22}{1+5,09}=\frac{22}{6,09}=3,61=4$

From the table of post-test score interval and frequency, the writer presented the data of posttest in chart.

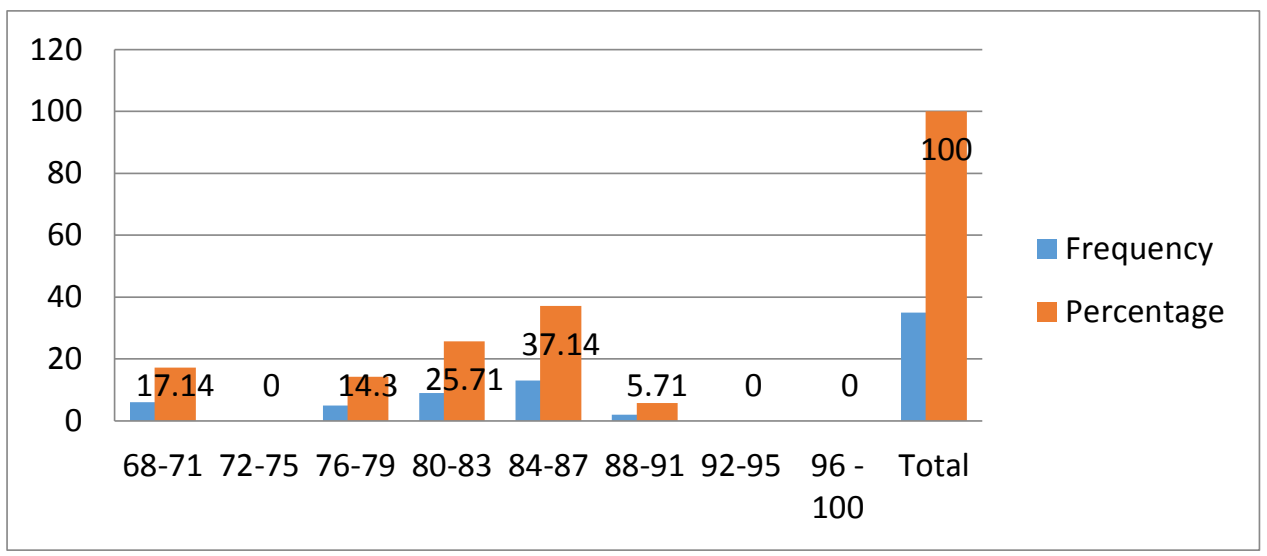

Figura 3. The Histogram of Post-test

From the histogram of post-test, the highest frequency for score interval 84-87 are 13 students $(37,14 \%)$. The lowest of frequency for score interval $72-75,92-95,96-100$ is 0 . It means no one students could achieve those score. Then, frequency for score interval 68-71 are 6 students $(17,14 \%)$, frequency for score interval $76-79$ are 5 students $(14,30 \%)$, and the last frequency for score interval $88-91$ are 2 students $(5,71 \%)$.

To find out the students' mean score in each test, the writer applied the following formula :

$$
\bar{x}=\frac{\sum x}{N}
$$

From the formula above, the result of the students' mean score could be seen as follows:

a. In pre test, the total score of the students is $\frac{2008}{35}=57,37$

b. In formative test, the total score of the students is $\frac{2480}{35}=70,85$

c. In post- test, the total score of the students is $\frac{2802}{35}=80,05$

Finally, from the result of the tables and chart of pre-test, formative test, and post-test the writer presented the conclusions of quantitative data as follows :

Table 4. Quantitative Data

\begin{tabular}{|l|l|l|l|}
\hline Component & Pre-test & Formative test & Post-test \\
\hline Mean & 57,37 & 70,85 & 80,05 \\
\hline Median & 56 & 72 & 80 \\
\hline Mode & 46 & 68 & 84 \\
\hline
\end{tabular}


To find out the percentage of the students' imrpovement score from pre-test, formative test and post- test, the writer applied the following formula.

Which:

$$
\mathrm{P}=\frac{y 1-y}{y} X 100 \%
$$

$\mathrm{P}=$ Percentage number of students

$\mathrm{y} 1=$ The number of those who get the higest mean

$\mathrm{y}=$ The number of those who get the lowest mean

Students' improve from pre-test to formative test :

$\mathrm{P}=\frac{70,86-57,37}{57,37} \mathrm{X} 100 \%$

$\mathrm{P}=\frac{13,49}{57,37} \mathrm{X} 100 \%$

$\mathrm{P} \quad=23,51 \%$

Students' improve from pre-test to post test :

$\mathrm{P}=\frac{80,06-57,37}{57,37} \mathrm{X} 100 \%$

$\mathrm{P}=\frac{22,69}{57,37} \mathrm{X} 100 \%$

$\mathrm{P} \quad=39,55 \%$

Thus percentage of the students' improve score from pre-test to formative test is $23,51 \%$ and from pret-test to post test is $39,55 \%$. The calculate percentage of students' improve score attached in appendix. From the table of quantitative data, The writer presented the quantitative data in the following chart.

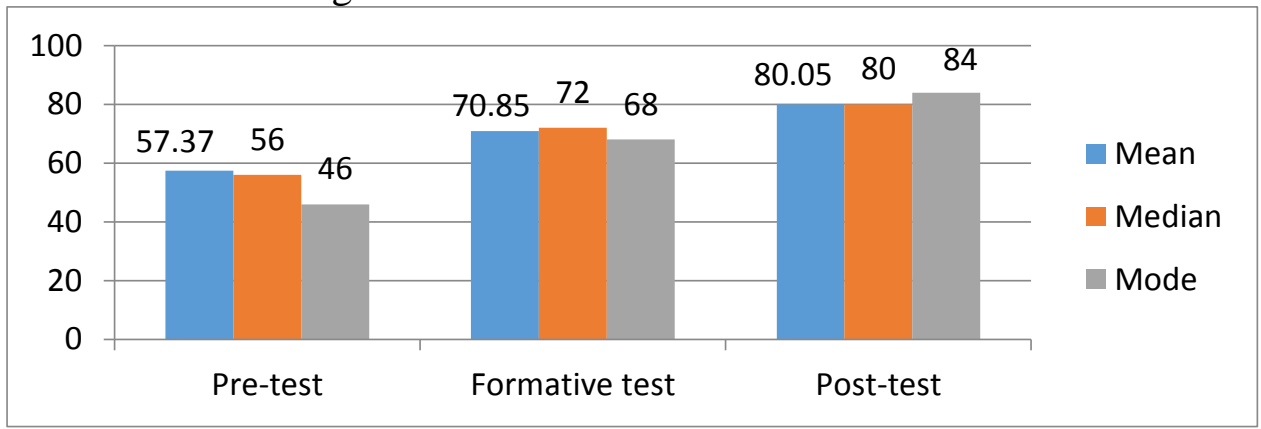

\section{Figura 4. The Histogram of Quantitative Data}

From the result of the students' score, it is concluded that the students mean score increases. It could be seen from the mean score in pre-test,formative test,and post-test. In pretest, the students' mean score is 57,37 while the students' mean score in the formative test is 70,86 and in post-test is 80,06 . Then the mode and median of the students'score in post-test are higher than pre-test. It means that there is development of the students' speaking skill through story telling technique. The percentage of the students'achievement in speaking test was presented as follows:

Table 5. Percentage of students' achievement who got score $=70$

\begin{tabular}{|l|l|l|}
\hline Test & Students who got score $\geq \mathbf{7 0}$ & Percentage \\
\hline Pre-test & $\mathbf{7}$ & $\mathbf{2 0 \%}$ \\
\hline Formative test & $\mathbf{2 1}$ & $\mathbf{6 0} \%$ \\
\hline Post-test & $\mathbf{3 1}$ & $\mathbf{8 8 , 5 7} \%$ \\
\hline
\end{tabular}

To find out the percentage of the the students who passed the Mastery Minimun Criteria (Kriteria Ketuntasan Minimal ) in the test, the writer applied the following formula:

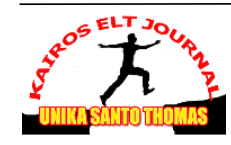


KAIROS ELT JOURNAL, Vol. 2, No. 1, April 2018

Copyright@ 02018 , ISSN: 2580-4278

$\mathrm{P}=\frac{R}{T} \mathrm{X} 100 \%$

From the formula above, the results of the students' percentage score could be seen as follows

a. In the pre-test, the total number of the students who pass the KKM is

$\mathrm{P}=\frac{7}{35} \mathrm{X} 100 \%=20 \%$

b. In the pre-test, the total number of the students who pass the KKM is

$\mathrm{P}=\frac{21}{35} \mathrm{X} 100 \%=60 \%$

c. In the pre-test, the total number of the students who pass the KKM is

$\mathrm{P}=\frac{31}{35} \mathrm{X} \quad 100 \%=88,57 \%$

From the percentage of students' achievment the writer presented the data in histogram.

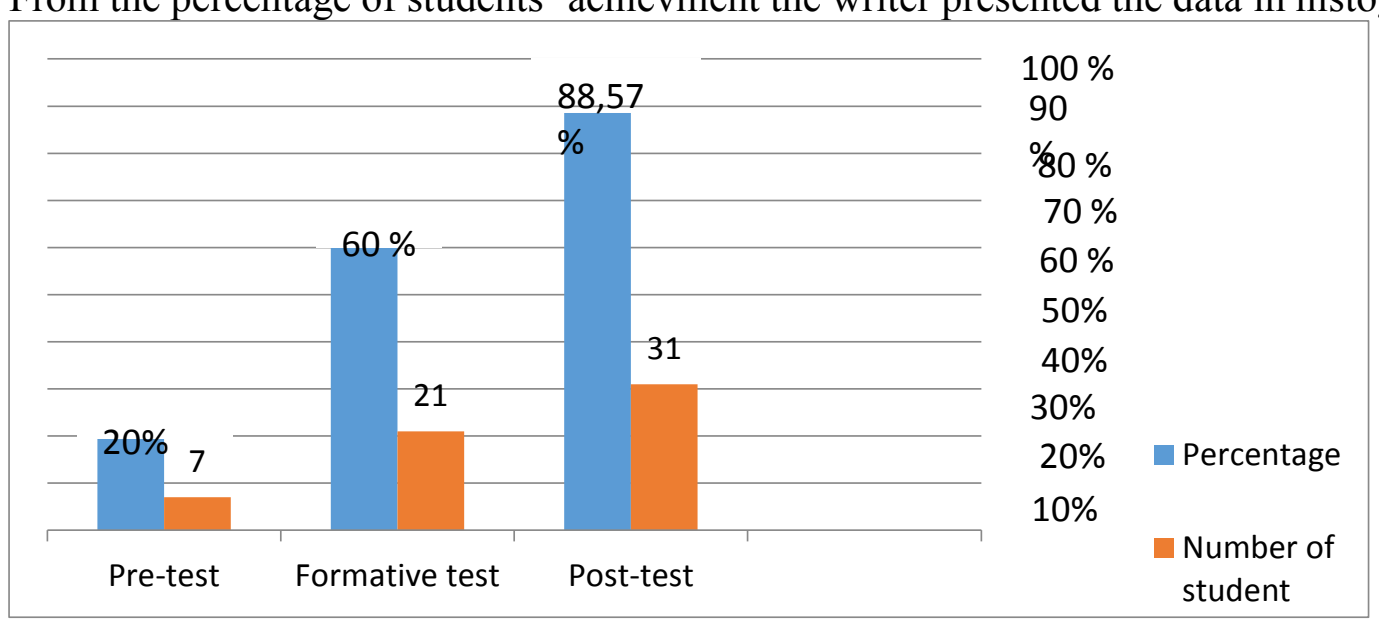

Figura 5. The histogram of persentage of students' achievement who got score $\geq 70$

\subsection{The Qualitative Data}

The qualitative data were taken from observation sheet, field notes, and questionnaires. The qualitative data are elaborated as follows :

\subsubsection{Fiel Notes}

Field notes are used to collect the data of students' activity during the teaching learning process. The writer wrote down the field notes in every meeting during the research was conducted. The detail of the process could be seen in the following explanation.

\section{Pre test : Thursday August $2^{\text {nd }} 2018$}

The writer came to the class with the English teacher as collaborator. The English teacher greeted the students then the leader of the class gave a command to stand up and greeted the teacher. The teacher told the students that researcher would replace him during the research. After that the English teacher asked the researcher to introduce herself and her purpose. The researcher greeted the students and told about her purpose. After that the teacher gave the learning process to the reseacher. Then, the researcher asked the students to do the pre-test before treatment was given in the next meeting. The reasearcher asked the students to describe about their close friend and gave them time around 5 minutes to prepare it and after finkishing their description students must speak up in font of the class. They were really suprised because they did not have any preparation at all. The class was so noisy for a while because they tried to ask one each other, but the researcher explained that they did not need to worry about that, the researcher asked them to speak what they know about their friend. During the test they look so nervous, many of them did not know what to say. The research recorded student's speaking performances and the collaborator also gave the score for the student's speaking performances. After finishing the test the witer said leave taking.

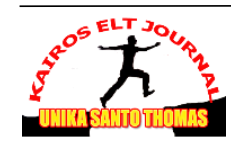




\section{The First Meeting : Tuesday August $7^{\text {th }} 2018$}

Teacher opened the class by greeting the students, asked about their condition and pointed out one of the students to lead the prayer.. The first material at the time was descriptive text. The teacher taught them decriptive text, it is about the social function, lexico grammatical features, and the example. After that, the teacher asked the students to describe about their close friend. It is very difficult for some students to describe about their friend, so the teacher let the students to make their note to help them when they spoke in front of the class. The teacher asked the students to describe about their friend in 15 minutes. After that the students asked the students one by one to tell about what they have written, every student is allowed to bring their note to help the students remember what they already written. In this meeting only six students spoke up in front of the class because the time was over. The teacher told them it will be continued in the next meeting.

\section{The Second Meeting : Thursday, August $9^{\text {th }} 2018$}

The teacher greeted the students, asked one of the students to lead prayer and then checked students' attendance list. After that, the teacher continued the previous material about descriptive text. The teacher asked the students about the material in last meeting. The students were asked to remember what they have already learned, and asked each students who didn't to spoke up in the last meeting. Many of the students looked so nervous and shy, it could be seen from their performances most of students forgot about what they already wrote and others looked so hesitate to ask, when finding unclear lesson from the material the chose to keep silent, then the teacher told them that in the next meeting the teacher will explain the material more clear. Teacher said leave taking to the students

\section{Formative test : Tuesday, August $21^{\text {nd }} 2018$}

The teacher greeted the students, asked one of the students to lead prayer and then checked students' attendance list. The students were asked to sit down and asked some questions related to the last material. In this part, The teacher explained about narative text and story telling technique and what students should do at the time. After explaining the material the teacher divided the students into 5 groups, each of group consist of 7 students. After the teacher divided them into some groups then the teacher gave them some common stories such as cinderela, keong mas,etc. From the example the teacher took Cinderela story and told it to the students briefly. After that, the teacher stick the picture on the white board, each group are free to choose the story that they wanted to retell. The students are allowed to open their dictionary and make their note during their preparation and also looked at their note in their performance. The students only had 15 minutes to make their preparation before speaking in front of the class. The students looked more active and cooperative one each other during their discussion. Although they still looked so nervous and not master the story because they often looked at their note and make pause in their performance. Besides some of them looked worried when speaking up. This could be seen from their short sentence. Some students made joke when speaking up, but the the class become relaxed for a while because all the students' laugh. In this meeting only two groups could perfom their story in front of the class because the time was over. Teacher told them it will be continued in the next meeting. After that the teacher said leave taking to the students.

\section{The Fourth Meeting : Thursday, August $23^{\text {rd }} 2018$}

The fourth meeting the teacher greeted the students, asked one of students to lead prayer, and checked the students' attendance list. After that the teacher continued the previous material about narrative text. The teacher asked the students about material in the last meeting. The teacher asked the student to sit down again with their group and each group that did not

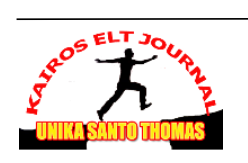


perfom their story, they have to perfom it in front of the class. At the time some groups seem not ready to perfom their stories so the teacher gave them 5 minutes to prepare everything they needed. After all groups perfom their stories, the teacher gave them correction about teir stories. For example give, come, fall, will, etc. The teacher correct their mistakes in grammar so that tehy not used the same mistake in next meeting. After finish the teacher asked the students to give applause. Teacher said leave taking to the students.

\section{The Fifth Meeting : Tuesday, August, $28^{\text {th }} 2018$}

The fifth meeting was the first meeting of teaching and learning process in cycle II. The teacher opened the class by greeted the students and asked students' condition. Before teaching the teacher asked one student to lead a prayer. Students were asked to sit based on their groups again after that the teacher did brainstroming by asking question related to the new learning material about narative text. The teacher taught them about the generic structure and how to make a narative text. The narrative text was about folklore, for example Kabayan. Then the teacher gave a story for them and asked them to discussed it with their groups. They were given 15 minutes to discuss the story. And then, all group performance their stories. The teacher said leave taking to the students.

\section{The Sixth Meeting : Thursday, August, $30^{\text {th }} 2018$}

The teacher greeted the students, asked one of students to lead prayer, and checked the students' attendance list. The students were asked by the teacher to sit down again with their groups before teacher explain about Simple Past Tense. After the explanation was clear teacher gave the example of folklore they were Kabayan. The teacher told to the students when they wanted to make a narrative text they have to used past tense. After that, the teacher asked them when they wanted to retell a story they did not need to focus on the text that have already given by the teacher, they only asked to retell the story based on what they have known. Then, the teacher gave a story and asked the students to sit with their groups. They also gave 15 minutes to prepare their story. Then the teacher asked them to perfomance it. The students looked so relax and fun at the time, and they really enjoyed their stories. After all group had perfomanced, then the teacher said leave taking to the students.

\section{The Seventh Meeting : Tuesday, September, $4^{\text {th }} 2018$}

The teacher greeted the students, asked one of students to lead prayer, and checked the students' attendance list. In this meetingb were asked to sit their groups again and then the teacher asked student about their difficulties in learning narrative text and simple past tense and made them clear for them. Teacher aslo emphasized that students should use simple past tense while spoke up about narrative text, so they gave time to disscuss and ask it again to the teacher. In last meeting of treatment by using story telling technique, teacher saw that students were fluent and confident in speaking and pronounciation were better. It was really different from the first meeting until the last. However there were students who were low in their speaking performance but it was better than the previous meeting in the cycle I. They had tried to de their best and they had tried to speak up though they felt difficult to begin at first. Then the teacher concluded all about the material, gave review all the materials from the first meeting until today at home and students prayed and said leave taking.

\section{Post test : Thursday September $6^{\text {th }} \mathbf{2 0 1 8}$}

The eight meeting was the last meeting of teaching and learning process in cycle II in which students would ask to do a test. The teacher greeted the students, asked one of students to lead prayer, and checked the students' attendance list. Then, the writer did brainsorming by asking students some questions about previous lesson. Then the teacher asked students to move

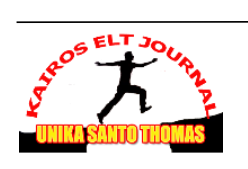


directly and sit down with their groups because they would have a speaking test. Teacher explained that the students would be asked to speak up as usual they did in treatment but in this chance teacher would take the score of their speaking performance and their friends could not help them as long as they speak to present about their ideas although they sat down in groups. In this test, they still had time to discuss for 15 minutes about the topic given but they could not help their friend in their in their groups while speak up although their friend asked about vocabulary and how to pronounce it. They followed the test and the rules well. They tried to speak up and develop their ideas fluently, but there were still some students who were mispronunciation and very slow in their speaking performance. However there were some students who were very fluent, smooth, and almost none of mispronunciation but they were not be taken for a native speaker. The test took 60 minutes in which the story was folklore. After the test had finished, teacher asked the students to fill the questionnaires for 15 minutes and teacher as the writer thanked all the students and the collaborator for 1 month conducted the research in the classroom. Before closing the class teacher and students took photos, prayed and said leave taking.

\subsubsection{Observation Sheet}

Observation sheet was focused on the problems, facts, situation and description during the teaching and learning process including students' activities and interaction in the classroom. The observation sheet was made by the writer to be checked by the teacher who acted as collaborator and observed the teaching and learning process in the cycle 1 and cycle 2 (could be seen in appendix 2). The story telling technique was applied in the process of teaching speaking in the classroom. The complete data can be seen as follows:

Table 6. Observation Sheet Cycle I and cycle II

Data $\quad:$ August $7^{\text {th }}, 9^{\text {th }}, 21^{\text {st }}, 23^{\text {rd (Cycle 1) }}$ and $28^{\text {th }}, 30^{\text {th }}, 4^{\text {th (Cycle 2) }}$

Collaborator : Hiras P. Hasibuan

Students : Class XI MIPA 4 SMA Swasta Katolik Budi Murni 2 Medan

\begin{tabular}{|c|c|c|c|c|}
\hline \multirow{2}{*}{ CRITERIA } & \multicolumn{2}{|c|}{ Cycle I } & \multicolumn{2}{|c|}{ Cycle II } \\
\hline & YES & NO & YES & NO \\
\hline \multicolumn{5}{|l|}{ TEACHER } \\
\hline $\begin{array}{l}\text { 1. The teacher prepares teaching material } \\
\text { systematically. }\end{array}$ & $\checkmark$ & & $\checkmark$ & \\
\hline $\begin{array}{l}\text { 2. The teacher explains the objective of } \\
\text { teaching. }\end{array}$ & $\checkmark$ & & $\checkmark$ & \\
\hline $\begin{array}{l}\text { 3. The teacher does brainstroming to } \\
\text { introduce the topic. }\end{array}$ & $\checkmark$ & & $\checkmark$ & \\
\hline 4. The teacher expalains the material clearly. & $\checkmark$ & & $\checkmark$ & \\
\hline $\begin{array}{l}\text { 5. The teacher responds the students' } \\
\text { questions and gives chance to all students } \\
\text { to ask the topic. }\end{array}$ & $\checkmark$ & & $\checkmark$ & \\
\hline 6. The teacher concludes the lesson. & $\checkmark$ & & $\checkmark$ & \\
\hline $\begin{array}{l}\text { 7. The teacher manages time effectively and } \\
\text { efficiently. }\end{array}$ & $\checkmark$ & & $\checkmark$ & \\
\hline \multicolumn{5}{|l|}{ STUDENTS } \\
\hline $\begin{array}{l}\text { 1. The students pay attention to the } \\
\text { teacher's explanation. }\end{array}$ & $\checkmark$ & & $\checkmark$ & \\
\hline $\begin{array}{l}\text { 2. The students ask the teacher if there is } \\
\text { something unclear. }\end{array}$ & & $\checkmark$ & $\checkmark$ & \\
\hline
\end{tabular}

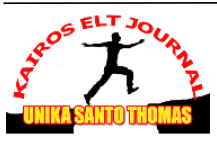


KAIROS ELT JOURNAL, Vol. 2, No. 1, April 2018

Copyright $\odot 2018$, ISSN: 2580-4278

\begin{tabular}{|l|r|r|r|r|}
\hline $\begin{array}{l}\text { 3. The students feel interested in teaching } \\
\text { learning process. }\end{array}$ & $\checkmark$ & & $\checkmark$ & \\
\hline 4. The students do exercises seriously & $\checkmark$ & & $\checkmark$ & \\
\hline SITUATION & \multicolumn{4}{|l|}{} \\
\hline $\begin{array}{l}\text { The classroom is comfortable (clean, } \\
\text { calm and organised) }\end{array}$ & $\checkmark$ & & $\checkmark$ & \\
\hline 2. The classroom is not noisy & & $\checkmark$ & $\checkmark$ & \\
\hline $\begin{array}{l}\text { The classroom has teaching aids } \\
\text { (whiteboard, marker and proyektor) }\end{array}$ & $\checkmark$ & & $\checkmark$ & \\
\hline
\end{tabular}

From the observation sheet that the writer focused on the situation of teaching learning process. We could see that there were the improvement of student from cycle 1 into cycle 2 . In cycle 1 , there were some of students not active in asked the teacher if there were something unclear. It happened because there were some students were not pay their attention to the teacher.

However in cycle 2, there were most of students were active in asked the teacher because in teaching learning process they pay full their attention. They have tried to do their best. The observation sheet showed that the teaching learning process by using story telling technique was carried out well. It could be seen from students' responses and the improvement of their performance when they spoke up in front of the class during teaching learning process in the classroom.

\subsubsection{Questionnaire}

Questionnaires were conducted to know the students' responses in teaching learning process through story telling technique whether the technique was appropriate with improvement of speaking skill or not. Questionnaire was taken at the end of the research finishing to conduct research both in cycle 1 and cycle 2 (could be seen in appendix 3 ). The questionnaire consisted of five items. It was filled by the students. It can be seen as follows:

Table 7. The Result Percentage of the Questionnaire

\begin{tabular}{|l|l|l|l|l|l|}
\hline No & Sudents' Contribution & Yes & Percentage & No & Percentage \\
\hline 1 & $\begin{array}{l}\text { Do you feel happy join this learning } \\
\text { process? }\end{array}$ & 34 & $97,14 \%$ & 1 & $2,85 \%$ \\
\hline 2 & $\begin{array}{l}\text { Do you think story telling technique } \\
\text { can build up your motivation in } \\
\text { learning English especially in } \\
\text { speaking? }\end{array}$ & 29 & $82,85 \%$ & 6 & $17,14 \%$ \\
\hline 3 & $\begin{array}{l}\text { Does story telling make you } \\
\text { interested in English language? }\end{array}$ & 31 & $88,57 \%$ & 4 & $11,42 \%$ \\
\hline 4 & $\begin{array}{l}\text { Does story telling can build up } \\
\text { speaking skill? }\end{array}$ & 32 & $91,42 \%$ & 3 & $8,57 \%$ \\
\hline 5 & $\begin{array}{l}\text { Does your speaking skill improve } \\
\text { after story telling techniqueis } \\
\text { applied? }\end{array}$ & 31 & $88,57 \%$ & 4 & $11,42 \%$ \\
\hline
\end{tabular}

Table 7. presented the result of the questionnaire of the eleventh grade students in SMA Swasta Katolik Budi Murni 2 Medan. Based on the questionnaires from 35 students of the eleventh grade as respondents, thier responses were very good. The first item showed $97,14 \%$ students were happy joined the learning process and $2,85 \%$ students were not happy joined the learning process. The second item showed 82,85\% students motivated in learning English especially in 
speaking and $17,14 \%$ students not motivated in learning English especially in speaking through story telling technique.

The third item showed 88,57\% students interested in learning English and 11,42\% students not interested in learning English by using story telling technique. The fourth item showed $91,42 \%$ students could build up their speaking skill and 8,57\% students could not build up their speaking skill by using story telling technique. And the last item, 88,57\% students could improve their speaking skill and 11,42\% students could not improved their speaking skill after story telling was applied. Based on the result of the questionnaires, it could be concluded that students' response was very good for the story telling technique which was used to improve their speaking skill because from the fifth item, the percentages showed that students' response was highly positive.

\subsection{Discussion}

Story telling technique was applied to improve the students' speaking skill to the eleventh grade students of SMA Swasta Katolik Budi Murni 2 Medan. As the collaborator the English teacher and the writer collaboratively discussed the result of the study. They conclude that the use of story telling technique could be the effective way to help students in speaking. It was shown in histogram and table 4.4. In which the mean score of each test improved. The mean score of pre-test is 57,37. Formative test is 70,85 and the post test is 80,05 . Those score showed that the second cycle was better that the first cycle. Beside that, the improvement can be seen from the observation sheet, field notes and questionaire. The observation sheet showed that the teaching learning process by using story telling technique was carried out well. It could be seen from students' responses and the improvement of their performance when they spoke up in front of the class during teaching learning process in the classroom. Based on the the questionnaires that students' response was very good for the story telling technique which was used to improve their speaking skill because from the fifth item, the percentages showed that students' response was highly positive. Most of students were more active and enthusiastic during the process of teaching and learning start from the first to second cycle when the technique was applied.

In conclusion, story telling technique was suitable technique to improve students' speaking skill because this technique gave students a chance more active. Eventhough, the application of this technique requires a long time to implement in the classroom.

As the result, the students' speaking score test improved in both of cycle after being taught with story telling technique and also have good response and condition to all students in teaching learning process.

\section{CONCLUSION}

After conducting the research, presenting the data, analyzing the data and discussing the result, the writer is going to present conclusion and suggestion. They are drawn as follows:

1) The application of story telling technique can improve the students' speaking skill. It was found out that the students achievement of speaking skill on narrative text imroved from pre-test and post-test after story telling technique was applied. The increase of the students' total mean score in pre-test is 57,37 the formative test is 70,85 and post-test is 80,05 Meanwhile, the students' score percentage who was passed Mastery Minimun Criteria ( Kriteria Ketuntasan Minimal ) from pre-test is $20 \%$ the formative test is $60 \%$ and the posttest is $88,57 \%$, the students score percentage continously increased in each test. Therefore, it is concluded the application of story telling technique can improve the students' speaking skill on narrative texts succesfully.

2) The students' responses after being taught by story telling technique are very good. The questionnaires show that students strongly agree that story telling technique is interesting and suitable to improve their speaking skill. 


\section{BIBLIOGRAPHY}

Burns, A. 2000. Collaborative Action Research for English Language Teacher. Cambridge: Cambridge University Press.

Collis, J. \& Hussey, R. 2003. Business Research (First Edition). Hampshire: Palgrave Macmillan.

Ellis, G. \& Brewster, J. 1991. The Story Telling Handbook for Primary Teacher.Middlesex: Penguin Group.

Fisher, D. \& Frey, N. 2007. Checking for Understanding: Formative Assessment Techniques for Your Classroom. California: Association for Supervision and Curriculum Development (ASCD).

Halimah, D. N. 2016. Improving the Students' Vocabulary Mastery by Using Story Telling. An Unpublished Sarjana's Thesis, Islamic Education and Teacher Training Faculty: The State Islamic Institute of Surakarta.

Harmer, J. 2002. The Practice of English Language Teachning. London: Pearson Education. . 2007.The Practice of English Language Teaching (Fourth Edition).Edinburgh: Pearson Education.

Harris, P. D. 1969. Testing English As A Second Language. New York: Tata McGraw-Hill. 1974. Testing English As A Second Language . New York: Tata McGraw-Hill.

Ikrammuddin, R. 2017. Using Story Telling Technique to Improve Speaking Ability (Classroom Action Research on the Second Grade Students of Insan Qur'ani Boarding School). An Unpublished Sarjana's Thesis, Faculty of Tarbiyah and Teacher Training: Ar-Raniry State Islamic University.

Inayah, R. 2015. Improving Students' Speaking Skill through Story Telling Technique. English Language Teaching in Indonesia Journal, 3(1), 25-37.

Kemmis, S. \& McTaggart, R. 2010. Participatory Action Research. Boston: Denzin \& Lincon Strategies.

Lado, R. 1961. Language Teaching: A Scientific Approach. New Delhi: Grow Hill Publishing Company.

Mills, G. E. 2000. Action Research: A Guide for the Teacher Researcher. New Jersey: Merrill An Imprint of Prentice Hall.

Munaroh, S. 2012. Using Story Telling Technique to Improve Speaking Skills of the Students of MTS Al-Ghozali Panjerejo. An Unpublished Sarjana's Thesis, English Education Program: State Islamic College Tulungagung.

O’Malley, J. M. \& Pierce, L. V. 1990. Authentic Assessment for English Language Learner: Practical Approach for Teacher. Massachusetts: Addition Wesley. 
KAIROS ELT JOURNAL, Vol. 2, No. 1, April 2018

Copyright@2018, ISSN: 2580-4278

Purwatiningsih. 2015. Improving Speaking Ability through Story Telling Technique by Using Picture Series to the Tenth Grade Students of MAN 2 Madiun in Academic Year 2014/2015. Journal on English As A Foreign Language, 5(1), 61-62.

Richards, J.C. \& Rodgers, T.S. 1986. Approaches and Methods in Language Teaching: A Description and Analysis. Cambridge: Cambridge University Press.

Safdarian, I. 2013. The Effect of Stories on Young Learners' Proficiency and Motivation in Foreign Language Learning. International Journal of English and Education, 2(3), 200248.

Samantaray, P. 2014. Use of Story Telling Method to Develop Spoken English Skill. International Journal of Language and Linguistics, 1(1), 40-44.

Silaban, B., \& Limbong, T. (2017). Aplikasi Pembelajaran Pengenalan Kriptografi Algoritma Affine Cipher Dan Vigenere Cipher Menggunakan Metode Computer Assisted Instruction. Media Informasi Analisa Dan Sistem, 2(2), 14-20.

Sugiyono. 2013. Statistika untuk Penelitian. Bandung: Penerbit Alfabeta.

Taylor, E. 2000. Using Folktales. Cambridge: Cambridge University Press.

Turk, C. 2003. Effective Speaking: Communicating in Speech. London: Spon Press.

Ur, P. 1996. A Course in Language Teaching: Practice and Theory. New York: Cambridge University Press. 